\title{
Chinese and Indigenous Ethnic Cultural Communication in Palembang City
}

\author{
$1^{\text {st }}$ Nora Meilinda Hardi \\ Dept. of Science of Communication \\ Faculty of Social Science and \\ Humanities \\ Universitas Muhammadiyah Bandung \\ J1. Soekarno Hatta No.752 Soekarno \\ Hatta, Panyileukan Kota Bandung, \\ Indonesia \\ meilindanora@gmail.com
}

\author{
$2^{\text {nd }}$ Ulfa Yuniati \\ Dept. of Science of Communication \\ Faculty of Social Science and \\ Humanities \\ Universitas Muhammadiyah Bandung \\ Jl. Soekarno Hatta No.752 Soekarno \\ Hatta, Panyileukan Kota Bandung, \\ Indonesia
}

\begin{abstract}
Purpose of intercultural communication research to determine the influence of worldviews and indigenous ethnic Chinese in the city of Palembang. Three elements of the worldview that includes the study of religion or beliefs, values and behavior, which is part of the theory of cultural perception by Larry A Samovar, Richard E. Porter dan Edwin R. McDaniel. This study uses a qualitative phenomenological approach which aims to look at various situations or social realities that apply to ethnic Chinese and indigenous in the city of Palembang. Research using depth interviews with a number of ethnic Chinese and indigenous informants. In addition, the observation and analysis of literature related to this research. Analysis of the data is written in a narrative inductive. An important result showed that religion/belief is one that is right and not be forced. However, through the marriage of the ethnic Chinese and indigenous religious conversion to Islam and Christianity that religions outlook changed. In addition, intercultural communication can change the perspective of the cultural values of ethnic Chinese and Natives in the city of Palembang. There by encouraging individual behavior becomes positive and its worldview.
\end{abstract}

\section{Keywords-Chinese, Indigenous, Ethnic, Cultural}

\section{INTRODUCTION}

Cultural perception is a perspective which of course may be the same and also different in a person in viewing others (his own group, or other groups). Problems that often arise based on previous studies exist on different views in looking at other groups or ethnicities, so that it tends to cause difficulties in communicating between cultures and can affect interactions between various ethnicities. The results conducted by Jelena that there will be a misunderstanding felt by ethnic identity and the reaction that occurs is based on a person's previous experience [1].

In his theory said that there are three main elements that shape cultural perceptions and have a large or direct influence on individual participants in intercultural communication. The first is a worldview (belief system or religion, cultural values and behavior), the second is a symbol system (verbal and non-verbal) and thirdly a social organization (family and institution) [2, pp. 12-14]. Palembang with its heterogeneous society from various ethnic groups with cultural experiences that background it makes the dynamics of intercultural communication so beautiful that it can often lead to misunderstanding, uncertainty and even conflict because each party does not try to understand each other.

There is a strong tendency for each ethnic group to maintain their identity as in the use of local languages when meeting their ethnic groups, feeling their ethnicity is better than other ethnic groups. Each ethnic group tends to view the norms and values of their cultural groups (social organizations) as something absolute and can be used as a reference to measure and act against other cultural groups.

The findings of Agustrisno supported by the author's observations in several places in the city of Palembang [3], [4]. Palembang Chinese still excludes themselves (choosing a place to live, shopping for daily necessities, choosing a children's school). This is inseparable from the author's observations on the ownership of the residence in a fellow in groups such as Komplek 10 Hulu, 26 Ilir, Tujuh Hulu, Kampung Kapiten Area. Also in shopping for daily necessities, they prefer their community such as the 26 Ilir market, Ramayana market, Dempo market. Likewise, in the selection of children's schools, such as Xaverius School, Kumbang School, Budhiss School, and others (observation, December 2019).

In fact, there is one area that is almost 100 percent inhabited by ethnic Chinese, namely in the Sukaramai II sub-district of Palembang District (interview with the Village Head, December 2019). The city center and main 
roads are almost entirely controlled by ethnic Chinese as trade and service centers. Especially after seeing the Central Statistics Agency data, the ethnic Chinese community occupies the third-largest position with a population of 202,839 people [5].

Based on the description above makes the rationale and attention of the author to carry out this research in the city of Palembang. The problem to be examined is how intercultural communication can change the worldview of ethnic Chinese and natives in the city of Palembang. Specifically, what will be examined are the three elements of worldview, namely religion or beliefs, cultural values, and behavior.

\section{RESEARCH METHODS}

The research method is qualitative using a phenomenological perspective. In the view of Edmund Husserl [6, p. 12], phenomenologists try to understand culture through the view of the owner of the culture or the culprit. Phenomenological studies by attempting to explain the meaning of cultural experiences of ethnic Chinese and natives, namely regarding the cultural worldview of each ethnic group in viewing and valuing other ethnic groups making it easier for them to communicate across cultures. Husserl's phenomenology aims to find the essential or essence of phenomena [7].

Informants were selected based on purposive sampling, amounting to 10 people. Adjusted with the aim of researchers to get good results.

\section{RESULT AND DISCUSSION}

In this study the results of interviews with informants who were then investigated were divided into several categories, including: religion or belief, values, and behavior. Phenomenology as a descriptive and introspective analysis of the depth of all forms of

consciousness and direct experiences: religious, moral, aesthetic, conceptual and sensory [8].

A. Religion or belief

Based on interviews and participatory observations, it can be seen that there are variations that illustrate the cultural character of each informant's experience with what is perceived, carried out and observed from the existing social reality must be recognized and respected. Religion or beliefs and values must be combined about good and bad, halal and haram, as well as what may and may not be done according to their religion and beliefs.

This affects the values that were originally adopted to change and can be seen from the behavior of the informants in interacting more flexibly. In a sense it is not only fellow in group, but has mixed with other indigenous ethnicities. The results showed that religion or belief is a right for every human being. In the ethnic Chinese community in the city of Palembang, many of them still adhere to the syncretic belief that has been passed down for generations. Unlike the case with indigenous ethnic groups who are generally Muslim or Christian. However, due to intermarriage between ethnic groups, the conversion of religion, especially to Islam, is not an easy thing for ethnic Chinese.

Even in the writer's observation of the family of Herdianti, for the case of families with converts, it is clear that families with partners of different religions will have greater challenges in dealing with differences in values and habits in their role as parents than couples who originate from one religion or belief. The greater challenge faced is in adjusting differences (cultural values) and the way of raising children the informants told the authors, so that both of them believe that the Islamic school is the right choice to educate their children so that the formation of their children's religious knowledge is better.

\begin{tabular}{lll}
\hline No & \multicolumn{1}{c}{ Informants } & \multicolumn{1}{c}{ Said } \\
\hline 1 & Nuraini (Key Informant) & $\begin{array}{l}\text { Chinese converts always get opposition from their family and } \\
\text { community environment". This is also the case with some of } \\
\text { the informants below. }\end{array}$ \\
\hline $2 \quad$ Herdianti (40 years old, ethnic Chinese selling fried food) & $\begin{array}{l}\text { At first converting to Islam for religious activities (studying } \\
\text { Islam) is always carried out clandestinely, afraid of being } \\
\text { known. Enter Islam because of the awareness of the truth of } \\
\text { Islam through a long process and supported by a Muslim } \\
\text { neighborhood and relatives }\end{array}$ \\
& $\begin{array}{l}\text { Ten years ago, the beginning of entering the religion of Islam } \\
\text { was a difficult thing, plus being discarded in a large family for } \\
\text { more than two years. All business opportunities are taken over } \\
\text { by the family (parents). This does not make me afraid because } \\
\text { the choice of Islam is a right }\end{array}$ \\
\hline
\end{tabular}

Fig. 1. Religious and Beliefs

Furthermore, the findings of interview data found that ethnic Chinese converts had been marginalized from the nuclear family and extended family because they were considered unlucky and some were even considered no more children after switching to Islam and marrying one native ethnicity (Muhammad Fendy Leong's case). Even more impressive is the author's observation of the ethnic Chinese converts where trade relations stopped because trade generally grew and developed from family trade relations. As quoted by Bob Widiyahartono, for centuries the Chinese nation had a world view that individuals are part of the family, family part of the tribe, and tribe part of 
the nation. So, it can be understood in the trade that Chinese businessmen always partner with family members and friends [9].

What the author gets, in fact, is in line with research conducted by Glammer on the ethnic Chinese Baba in Melaka [10, p. 1] that the Chinese people who adhere to Buddhism and Christianity do not find obstacles to continue carrying out the teachings of ancestors who have been believed. But regarding the transfer of beliefs or religions to Islam is very different, not just stating the transfer of beliefs or religions but includes changes in cultural identity. This means that belief in Islam is a form of awareness of religious life through a long process.

Religious views changed due to the process of mixing culture (melting pot) in people who converted to Islam much faster because the ethnic Chinese converts were welcomed very well and joyfully by their new family, community groups, and the majority Muslim environment (Herdianti case). By Junus Jahya in Tan said that switching to Islam was seen as the final act or perfection of the integration process. Automatically the assimilation process will be faster if the religion is the same [11].

Other research in the city of Medan, through a marriage between ethnic Chinese and Indigenous people there was a conversion so that the views of religion also changed [12]

\section{B. Values}

The results showed that in Palembang the role of ethnicity was not prominent because there was no dominant or majority ethnic group here. However, the prominence of "sense of me" that considers superior to "sense of you" in other ethnic groups has begun to diminish due to marriages between ethnic Chinese and Indigenous people, conversion of religions or beliefs, work environment and residence. Almost all informants interviewed no longer maintain norms or values, but also openly accept positive values from other ethnic groups.

The informants realized that to quickly change values that had become a view of life was not easy, it needed time and frequency of intercultural communication that was often done.

\begin{tabular}{|l|l|l|}
\hline No & Informants & Said \\
\hline 1 & $\begin{array}{l}\text { Ratna (age 33, occupation of a vegetable } \\
\text { trader) }\end{array}$ & $\begin{array}{l}\text { The Chinese have strong values as hard workers and are not easily discouraged, } \\
\text { different from the values that exist in native people who like to lazy when there is (a lot } \\
\text { of) money. So on, the average Chinese person is good, but his kindness sometimes } \\
\text { depends on his circumstances. The point is that with people who are considered } \\
\text { insignificant they separate themselves and don't get along too much. Even if you want } \\
\text { to get along because there are only interests. It's different from us natives, just as we } \\
\text { are in getting along, if it really can be helped yes it is helped and if it can't be that is just } \\
\text { plain }\end{array}$ \\
\hline 2 & $\begin{array}{l}\text { Lia Dahlia (21 years old ethnic Chinese student } \\
\text { UNSRI) }\end{array}$ & $\begin{array}{l}\text { I think that natives are generally doing well. I'm not in a lot of trouble dealing and have } \\
\text { native friends from various ethnicities. I am comfortable with friends with indigenous } \\
\text { people because this has been my parents' habit since I was a child. In fact, two of my } \\
\text { brothers are married to natives and are Christians like other natives in the village of } \\
\text { captives who are predominantly of Chinese descent }\end{array}$ \\
\hline 3 & $\begin{array}{l}\text { Lia Dahlia (age 43 years), as a housewife and } \\
\text { neighbor with ethnic Chinese in the Kapiten } \\
\text { complex for more than ten years }\end{array}$ & $\begin{array}{l}\text { Not all Chinese are ugly, but in Palembang they seem to dominate (unlike in Padang, } \\
\text { Makassar and Bandung they melt) so that there seems to be a social distance between } \\
\text { the Chinese and the natives. Generally they are individualists and do not want to } \\
\text { interact with natives like those in my complex. Likewise they can be trusted for business } \\
\text { matters }\end{array}$ \\
\hline
\end{tabular}

Fig. 2. Values

\section{Behavior}

Behavioral factors are interpretations of the values affirmed by each cultural group. Cultural behavior of an ethnic group is a tendency obtained by learning to respond to an object consistently. Data collected from the informants generally acknowledged that discriminatory treatment still continues to this day, both for Chinese and natives. Besides that, between each ethnic group, the others still looked sideways in accordance with previously formed stereotypes so that there was still prejudice and distance between the Chinese and the indigenous people in Palembang. Communication actively applies to others in the group. When outside the group communication is only limited to express things that are important. Except for ethnic Chinese and natives who have entered into mixed marriages or conversions or beliefs in Islam or Christianity, they feel that they are one big family. 


\begin{tabular}{|c|c|c|}
\hline No & Informants & Said \\
\hline 1 & $\begin{array}{l}\text { Eka (aged } 35 \text { years Javanese), } \\
\text { worked as a Chinese maid for } \\
\text { more than three years }\end{array}$ & $\begin{array}{l}\text { At the beginning I worked as a Chinese housemaid, my employer looked at the natives as lazy, working a little money } \\
\text { and a lot of money. So he likes being stingy to the natives, including me. In social behavior, he prefers to live in groups } \\
\text { with fellow Chinese people in the housing complex so as not to be disturbed and more comfortable, he said. Likewise } \\
\text { in the case of the selection of children's schools, they tend to choose private schools for their children so that } \\
\text { problems do not arise with native children and teachers in public (government) schools. }\end{array}$ \\
\hline 2 & $\begin{array}{l}\text { Mukti Muhlisisn ( } 60 \text { years), a } \\
\text { UNSRI Lecturer and has } 50 \text { years } \\
\text { of close friendship with a } \\
\text { Chinese friend }\end{array}$ & $\begin{array}{l}\text { Discrimination between ethnic Chinese and natives exists, natives have ruled out Chinese and Chinese have formed } \\
\text { exclusive groups. Chinese, on the other hand, also behaved in the same way so that the natives felt humiliated. } \\
\text { Likewise, don't look at stereotypes excessively because we are both Indonesian citizens. As the ethnic Chinese } \\
\text { behavior must be changed, do not look at the natives, all are lazy, blackmailed, angry, do not respect the time and } \\
\text { unlucky friendship with the natives. Conversely, indigenous behavior must also be changed, do not like to suppress } \\
\text { and use Chinese for personal and group interests. Also don't consider all Chinese to be rich (lots of money). Because, } \\
\text { there are among ethnic Chinese who are poor and have enough income to eat just like my colleague who works as a } \\
\text { vegetable grower. Therefore, it is necessary to form trusts through personal relationships. The experience between } \\
\text { cultures must be broadened with positive thoughts such as through education, everyday associations and social } \\
\text { organizations }\end{array}$ \\
\hline 3 & $\begin{array}{l}\text { Vera Arica (aged } 20 \text { years ethnic } \\
\text { Chinese), UNSRI student }\end{array}$ & $\begin{array}{l}\text { His relationship with natives such as friends at school and university, housemaids who work at his house are quite } \\
\text { good, respect each other and respect and behave modestly. This is needed to underlie interpersonal relationships. I } \\
\text { feel that there is discrimination by thinking that the Chinese are foreign. I am not discouraged and say that not all } \\
\text { Chinese group themselves (exclusively). For example, me and my parents, in choosing a place to live, they don't have } \\
\text { to be fellow ethnic Chinese. With the natives, it is also allowed as long as the housing area is safe and comfortable } \\
\text { and the ethnic natives want to be friends with me. Discrimination and stereotypes arise due to lack of interaction and } \\
\text { communication with other ethnic groups }\end{array}$ \\
\hline 4 & $\begin{array}{l}\text { Karen (age } 22 \text { Chinese ethnic), a } \\
\text { student of UNSRI }\end{array}$ & $\begin{array}{l}\text { At first I perceived the natives (not all) to behave rudely, not wanting to be friendly with the Chinese, we liked to be } \\
\text { teased with the words 'Chinese Luh', being squeezed and treated unfairly. Over time and my association with the } \\
\text { natives, my perception has changed a lot in looking at the natives. Many of them behave friendly and polite and } \\
\text { respect each other, do not want to blackmail and cheat. The thing that I think about is that the stereotype is formed } \\
\text { depending on whether or not someone gets along and wants to be open with other ethnic groups. Right now I have } \\
\text { friends who are predominantly of indigenous ethnic groups besides the nuclear family. Even if there is discrimination } \\
\text { already getting smaller, the main thing is to have to be good at carrying yourself wherever you are }\end{array}$ \\
\hline
\end{tabular}

Fig. 3. Behavior

The discovery of the data above, the behavior is formed from a process of learning from culture and what is in the environment. As said by Samovar, et al. (2012: 17-19) that: "... the habits of various ethnic groups are a cultural force that influences the form of human behavior including its communication behavior". By looking at the general comments of the informants it can be said that it is acceptable that discriminatory behavior, stereotypes, prejudice, and social distance are a reflection of the lack of harmony between intercultural communication between ethnic Chinese and natives in Palembang until now. Therefore, the intensity of intercultural communication needs to be carried out continuously in order to establish harmonious relations.

\section{CONCLUSION}

The world view is a structure that is influenced by the culture where culture has accepted a variety of roles, then mobilizes or forms a passion for individuals to explain an event. Often the worldview is regarded as a formula of perception and fundamental assumptions which include the way a culture teaches its members to explain a belief system or religion, good and bad values, and ways of behaving.

The conversion of Chinese ethnic religions or beliefs to Islam or Christianity which is generally caused by marriages with indigenous ethnic groups has made a major contribution as one of the cultural aspects that have played a role in changing perspectives between ethnic groups. The choice of religion is due to the fact that Islam and Christianity are folk religions by indigenous communities in South Sumatra and especially in the city of Palembang. By increasing the frequency of intercultural communication, it will improve understanding of cultural values among ethnic Chinese and Indigenous people in the city of Palembang so that the world view of each ethnic group becomes wider and this can be seen from the display of attitudes or behaviors as perceived by research informants.

\section{REFERENCES}

[1] J. Durovic, "Intercultural Communication and Ethnic Identity," J. Intercult. Commun., pp. 1-11, 2015.

[2] L. A. Samovar, R. . Porter, and E. R. Mc.Daniel, Intercultural Communication: a reade, 11th (ed). Belmont, CA: Thomson/Wadsworth, 2006.

[3] S. Hadiluwih, "Konflik Etnik di Indonesia: Kajian Kes di Bandaraya Medan," Jabatan Antropologi dan Sosiologi, Fakulti Sastera dan Sains Sosial, Universiti Malaya, 2006, 2006.

[4] Agustrisno, "Respons Kultural dan Struktural Masyarakat Tionghoa Terhadap Pembangunan di Kota Medan," Universitas Padjadjaran, 2007.

[5] BPS, "BPS Palembang.pdf." 2010.

[6] E. Husserl, Ideas Pertaining to a Pure Phenomenology and to a Phenomenological Philosophy. Dordrecht: Springer Netherlands, 1982.

[7] A. Barbosa Da Silva, Phenomenology of Religion as a Philosophical Problem. 1982.

[8] M. Hariyanto, "Fenomenologi Transendental," Fenomenol. Transendental Edmund Husserl, no. 1906, 1938.

[9] B. Widyahartono and J. L. Vleming, Kongsi \& spekulasi : jaringan kerja bisnis Cina, Cetakan 1. Jakarta: Pustaka Utama Grafiti, 1988.

[10] Afif, Etnik Cina dalam Kehidupan Sosial Masyarakat Majemuk. Jakarta: Pustaka Utama Grafiti, 1999.

[11] M. G. Tan, Etnis Tionghoa Di Indonesia: Kumpulan Tulisan. Jakarta: Yayasan Obor Indonesia, 2008.

[12] L. A. Lubis, "komunikasi antar budaya etnis tionghoa dan pribumi di kota Medan," J. Ilmu Komun., vol. 10, no. 1, p. 14, 2012 . 